\title{
Latinamerika på zig zag kurs
}

Jens Lohmann

I de senere år har flere latinamerikanske lande fået mere eller mindre venstreorienterede regeringer. Det har skabt frygt i Washington og andre steder for et radikalt kursskifte i USA's "baggård". Men hvor meget er Latinamerika i virkeligheden drejet til venstre? Svaret er ikke entydigt

"Vi har flere gange i Latinamerika set hvordan de demokratiske institutioner er blevet svækket af de nye politiske ledere i det 21. århundrede". Mexicos tidligere præsident, Carlos Salinas de Gortari (1988-94), lagde ikke fingrene imellem over for de nye, kritiske og mere eller mindre venstreorienterede tendenser som de senere år er kommet til at præge Latinamerika, da han den 11. marts 2006 talte på en Latinamerikakonference organiseret af Massachusetts Institute of Technology (MIT).

Salinas lagde ikke skjul på at han ikke bryder sig om flere af de nye politiske ledere og deres holdninger, og advarede om at for tiden "hælder retorikken mere over til demagogi, og det kan være farligt for demokratierne i området". Han nævnte ingen navne, men det var ty- deligvis Venezuelas kontroversielle præsident Hugo Chávez og den ene kandidat til præsidentvalget i Mexico den 2. juli, Mexico Bys tidligere overborgmester, den moderat venstreorienterede Andrés Manuel López Obrador, han især lagde afstand til.

Salinas er en stærkt kontroversiel person i Mexico på grund af den valgsvindel der bragte ham til magten i 1988, den brutale privatiseringspolitik han gennemførte og den omfattende korruption han skal have deltaget $\mathrm{i}$.

Samtidig med at Salinas talte i Boston, blev Chiles nye præsident, den moderate socialist Michelle Bachelet, indsat i sit embede. I sin første tale som præsident mindedes hun sin far, flyvergeneral Alberto Bachelet, der blev fængslet og tortu- 
reret af militærfolk i 1974, fordi han havde været loyal over for den folkevalgte, socialistiske præsident Salvador Allende, som blev styrtet ved et militærkup den 11. september 1973. General Bachelet døde i fængslet. Hans datters tale var dog ikke bitter eller hævngerrig - selv om hun også blev fængslet og tortureret af diktaturet. Hun opfordrede tværtimod til forsoning.

\section{Bekymring i Washington}

Salinas de Gortaris kritiske advarsel mod de nye, globaliserings- og USAkritiske regeringer og politikere i Latinamerika er et ekko af den stigende bekymring i Washington over, at subkontinentet ikke længere som en selvfølge føjer sig efter USA's ønsker og behov. En bekymring som blandt andet er kommet til udtryk i skarpe udtalelser fra ledende amerikanske ministre og embedsmænd som da forsvarsminister Donald Rumsfeld i februar 2006 i National Press Club i Washington sagde at " $i$ Venezuela har vi Chávez, der har mange penge fra olien. Han blev valgt på lovlig vis, ligesom Hitler. Siden har han konsolideret sin magt og samarbejder nu med Fidel Castro, Mr. [Evo] Morales og andre".

Og han konkluderede, at "vi har set nogle populistiske ledere tiltrække folkemasserne i disse lande. Og valg der har fundet sted, som af Evo Morales i Bolivia, er klart bekymrende".
Washington kan have grund til at være bekymret over de senere års politiske udvikling i Latinamerika, men ikke på grund af den radikale diskurs hos præsidenter som Venezuelas Hugo Chávez og Bolivias Evo Morales. Ganske vist kan Chávez opvise økonomiske og sociale resultater af sin politik samtidig med at han klart støtter Cuba og kritiserer USA, og ganske vist er Morales tidligere leder af Bolivias coca-bønder og mangeårig aktivist på venstrefløjen. Chávez og Morales repræsenterer den mere radikale fløj af den modstand mod nyliberalismen, globaliseringen og USA's indflydelse, som er vokset bredt frem gennem den sidste halve snes år i de fleste latinamerikanske lande.

Men de er ikke repræsentative for de nye politiske ledere, som er blevet valgt i nogle af kontinentets vigtigste lande de senere år. Flere af dem er enten erklærede socialister eller socialdemokrater (Michelle Bachelet i Chile, Luiz Inácio Lula da Silva i Brasilien, Tabaré Vázquez i Uruguay, Oscar Arias i Costa Rica) eller socialliberale (Néstor Kirchner i Argentina), og alle er mere eller mindre kritiske over for USA og Den Internationale Valutafond (IMF).

\section{Voksende antiamerikanisme}

Ifølge en årlig måling som gennemføres af opinionsinstituttet Latinobarómetro på grundlag af interviews 
med 20.000 personer i 18 latinamerikanske lande forbedrede USA sit image i Latinamerika op gennem 1990'erne. I 2002 vendte tendensen, skarpest i Mexico, hvor $63 \%$ af de adspurgte i 2001 havde en positiv mening om USA, mod $41 \%$ i 2004. En næsten tilsvarende markant tendens blev målt i lande som Argentina, Uruguay og Bolivia, mens knap halvdelen af de adspurgte i Brasilien havde en positiv opfattelse af USA.

Antiamerikanisme er ikke et nyt fænomen i Latinamerika. Men antiamerikanismen i dag er anderledes end tidligere, da den var mere knyttet til venstrefløjen og højre- og venstrepopulistiske partier. I dag kommer antiamerikanismen i højere grad nedefra, og findes på tværs af politiske og ideologiske skel - og den lægger i modsætning til tidligere ikke op til brug af vold mod USA og amerikanske interesser, snarere til en bredere politisk, social og kulturel modstand mod USA og det, den mægtige nabo i nord repræsenterer.

Denne ændring hænger ikke mindst sammen med at kontinentet siden 1980'erne har oplevet en fremvækst af græsrodsbevægelser, der kæmper og arbejder for menneskerettigheder, miljø, indfødte folks rettigheder, sociale og uddannelsesmæssige forbedringer, og mod den nyliberalistiske, økonomiske politik IMF og USA påtvang regionens regeringer.

Den nyliberalistiske, såkaldte strukturtilpasningspolitik indebar kraftige nedskæringer og indskrænkninger i den offentlige sektor med massefyringer og omfattende privatiseringer - som mange steder betød milliardfortjenester til private investorer, ofte nære venner med præsidenter og ministre (det var således tilfældet i Mexico under Salinas de Gortari, der af samme grund er inderligt forhadt af mange mexicanere, mens han i udlandet hyldes af fortalere for nyliberalismen).

Den nyliberalistiske politik medførte - sammen med kraftig korruption og dårlig økonomisk styring også en kraftig vækst i udlandsgælden i flere lande. Følgen var, at den $\varnothing$ konomiske og sociale ulighed voksede og gjorde Latinamerika til det kontinent hvor gabet mellem rig og fattig er størst.

Mens USA scorede points da Clinton-regeringen i 1995 trådte til med 20 milliarder dollar for at redde Mexico fra total økonomisk kollaps, var Bush-regeringens afvisende holdning til Argentinas appel om $ø$ konomisk bistand, da landet brød økonomisk og politisk sammen i slutningen af 2001, medvirkende til at skærpe det kritiske image af USA hos latinamerikanerne. USA's tvetydige holdning i forbindelse med forhandlingerne om frihandelsaftaler med flere latinamerikanske lande hvor USA talte varmt for frihandel, men afviste at standse eller indskrænke milliardstøtten til nordamerikanske landmænd, bidrog til det 
negative image, især i lande som Argentina, Uruguay og Mexico.

Den amerikanske støtte til det mislykkede kup mod den demokratisk valgte Hugo Chávez i april 2002 skærpede antiamerikanismen. Desuden har den skrappere behandling af de hundredtusinder af latinamerikanere, der hvert år forsøger at komme ind i USA, øget animositeten over for USA, især i Mexico, Mellemamerika og Caribien, hvorfra de fleste illegale indvandrere kommer.

Det sidste skyldes dels at de skærpede restriktioner og den dårligere behandling berører mange almindelige mennesker, der videregiver deres erfaringer, dels at de ringere muligheder for at komme ind i USA og finde et arbejde indskrænker den kolossale strøm af penge legale og illegale indvandrere sender hjem til familien. For mange lande er pengene fra landsmændene i USA blevet en af de vigtigste valutaindtjeningskilder, i nogle lande den vigtigste.

\section{Ryggen til Latinamerika}

Endelig spiller det en rolle - ikke mindst i dele af den latinamerikanske politiske og økonomiske elite at USA's interesse for Latinamerika siden den 11. september 2001 nærmest er dalet til nul. Der hersker hos mange en følelse af, at Washington tager Latinamerikas støtte for givet. Det er baggården som man altid har kunnet regne med, som aldrig er gået afgørende imod USA.

At det ikke længere forholder sig sådan, måtte Bush-regeringen sande i månederne op til invasionen i Irak i marts 2003. I FN's Sikkerhedsråd vendte både Chile og Mexico - der ellers havde været betragtet som nære allierede til Washington - sig klart imod, at FN skulle støtte en USA-ledet invasion af Irak. I Argentina viste opinionsmålinger at hele $83 \%$ af befolkningen var imod krigen i Irak - det højeste tal nogetsteds i verden.

Antiamerikanisme er dog ikke det samme som venstreorientering. Men det er bekvemt og logisk for Washington at stemple den antiamerikanisme som findes i befolkningerne og som kommer til udtryk i nogle dele af flere regeringers politik som venstreorienteret retorik eller konkrete handlinger. Dermed legitimerer den amerikanske regering - især ved at trække de mere radikale præsidenter Hugo Chávez og Evo Morales frem som "typiske" repræsentanter for udviklingen - en skærpelse af sin politik over for kritiske regeringer, samtidig med at man holder en dør åben for forhandlinger, tilnærmelse og samarbejde med mere moderate regeringer.

Efter at have vendt ryggen til Latinamerika siden 2001, er Bush-regeringen $-i$ takt med at udviklingen $i$ Irak går stik imod de oprindelige forventninger om en nem etablering af et demokratisk, pro-vestligt styre - ved at få øjnene op for betyd- 
ningen af at ændre forholdet til de latinamerikanske lande. Den 16. marts fremlagde Bush' sikkerhedsrådgiver Stephen Hadley regeringens strategiske sikkerhedsprioriteringer. Irak, Iran og Mellemøsten har stadig højeste prioritet, men man synes at have opprioriteret forholdet til naboerne på den vestlige halvkugle - først og fremmest til de to nærmeste naboer, Canada og Mexico:

"Vores strategi for halvkuglen begynder med at uddybe vore nøglerelationer med Canada og Mexico på grundlag af fælles holdninger og politisk samarbejde, der kan udbredes til hele halvkuglen. Vi skal arbejde med vore naboer på halvkuglen for at reducere den ulovlige indvandring og fremme bredere økonomiske muligheder for de marginaliserede befolkningsgrupper".

Synet på de forskellige regeringer er dog ikke ændret. Om Chávez i Venezuela hedder det at han er "en demagog oversvømmet af oliepenge som undergraver demokratiet og søger at destabilisere regionen".

Om arvefjenden, Cubas Fidel Castro, der har knyttet nært venskab med Chávez, lyder det at han er "en antiamerikansk diktator der fortsætter med at undertrykke sit folk og søger at undergrave friheden i regionen”, mens Colombia, der styres af den konservative, meget USA-venlige Álvaro Uribe, beskrives som "en demokratisk allieret der bekæmper de vedvarende angreb fra marxisti- ske terrorister og narkohandlere". Colombia er det land i Latinamerika der modtager mest økonomisk og militær støtte fra USA.

\section{Latinamerikansk pragmatisme}

Altså intet substantielt nyt fra Washington over for Latinamerika bortset fra at man er forsigtig over for nøglelande som Brasilien, Chile og Argentina. Deres regeringer er næppe Bush-regeringens kop te, men de har på den anden side været moderate i deres sprogbrug og politik. Eller måske skulle man sige pragmatiske.

Det afspejler sig klarest i den politik, Brasiliens præsident siden 2002 har ført. Den erklærede socialist og tidligere fagforeningsleder Luiz Inâcio Lula da Silva vandt valget i 2002 på klare løfter om økonomisk fremgang og sociale og økonomiske forbedringer for landets millioner af fattige samt forhåndsforsikringer til landets mægtige økonomiske elite og de udenlandske selskaber i landet om, at han ikke ville gribe afgørende ind over for deres interesser.

Lulas diskurs var og er grundlæggende, hvad man må kalde venstreorienteret. Men han har - til stor skuffelse for mange af sine tilhængere - valgt ikke at følge en konfrontationskurs over for det kapitalstærke, private erhvervsliv og IMF. Kort efter sin tiltrædelse i 2002 overraskede han tilhængere og kritikere ved at understrege, at hans regering ville 
opfylde IMF's krav til landet til punkt og prikke. Det blev af fortalerne for en nyliberalistisk, markedsorienteret kurs taget som en sejr.

Lula har dog givet udtryk at han er kritisk over for nyliberalismen, men at det ikke er realistisk at søge en konfrontation. Det er bedre, siger han og hans rådgivere, at søge at forbedre og stabilisere økonomien, samtidig med, at der sættes gang i reformer inden for det økonomisk forsvarlige.

Dertil kommer at Lula har gjort sig til en af de mest fremtrædende talsmænd for et effektivt samarbejde med andre ulande - et Syd-Syd-samarbejde - som alternativ til det internationale system, der i dag er domineret af de rige lande i Nord. Brasiliens alliance med blandt andre Indien og Kina i WTO-forhandlingerne er et praktisk udtryk for denne kurs.

\section{Krise og alternativer}

Måske er der bedre muligheder for den brasilianske regerings satsning på at skabe et latinamerikansk økonomisk samarbejde som alternativ til det store frihandelsområde for hele den vestlige halvkugle, Free Trade Area of the Americas (FTAA), som USA gennem nogle år har forsøgt at etablere. Foreløbig er FTAA strandet, selv om der findes en aftale, og med tilslutning fra især Argentina, Venezuela, Uruguay og Bolivia kan et alternativt frihandelsområde for
Latinamerika muligvis se dagens lys.

Foreløbig er det dog ikke kommet langt, først og fremmest på grund af interessekonflikter mellem landene og forskellige visioner fra de interesserede regeringer. Den hidtil skarpeste konfrontation er uenigheden mellem Argentina og Uruguay om sidstnæuntes beslutning om at tillade opførelsen af et par store cellulose-fabrikker ved den store Uruguayflod, der også markerer grænsen mellem de to lande.

Argentina protesterer på grund af den frygtede store forurening af floden, Uruguay insisterer på opførelsen, som betyder mindst 1.800 hårdt tiltrængte arbejdspladser og forventede store eksportindtægter i det lille land.

Konflikten har skærpet krisen i det sydamerikanske frihandelsområde Mercosur (Argentina, Brasilien, Paraguay og Uruguay plus de associerede lande Bolivia og Chile), og sat spørgsmålstegn ved farbarheden af et geografisk mere omfattende, latinamerikansk økonomisk samarbejde.

Tvivlen understreges af at uruguayanske embedsmænd i slutningen af 2005 udtalte, at man overvejede at forhandle med USA om en frihandelsaftale - en overraskende melding for mange, som troede at præsident Tabaré Vázquez som landets første, erklærede venstrefløjspræsident ville prioritere det latinamerikanske samarbejde højest og afvise at underlægge sig de betingelser 
en frihandelsaftale med den nordamerikanske gigant indebærer.

Såfremt forhandlingerne indledes vil det skærpe krisen i Mercosur, da traktaten klart siger, at medlemslandene ikke må forhandle handelsaftaler med andre lande enkeltvis, men at de kun må forhandle som en samlet blok.

Samtidig arbejder Hugo Chávez energisk på at skabe et radikalt alternativ til det kriseramte Mercosur og til FTAA: Alternativa Bolivariana para la América (Det Bolivarianske Alternativ for Amerika) forkortet til ALBA, Morgengry. Bolivariansk er en hentydning til frihedshelten Simón Bolívar, som ledede kampen mod det spanske kolonistyre i det nordvestlige Sydamerika i begyndelsen af 1800-tallet. Bolívar blev født i det nuværende Venezuela, og Chávez har officielt døbt Venezuela til Bolivariansk Republik.

ALBA blev etableret som et tæt økonomisk samarbejde mellem Venezuela og Cuba, først og fremmest baseret på billige venezuelanske olieleverancer til Cuba til gengæld for 12-15.000 cubanske læger, som arbejder i landdistrikterne og mindre provinsbyer, og teknisk bistand og medicin fra Cuba. Chávez forsøger at udvide ALBA gennem billige olieleverancer til de små caribiske $\emptyset$-stater, Mellemamerika og naboerne i Sydamerika.

Samarbejdet bygger på barter-aftaler, det vil sige direkte udveksling af varer og ydelser, for at mindske af- hængigheden af dollar, der er det gængse betalingsmiddel på de kanter, og i øvrigt den valuta oliepriserne fastsættes i. Foreløbig finder der dog kun en begrænset udveksling sted. Argentina har således modtaget olie som betaling for drægtige racekøer, og Bolivia vil modtage olie og benzin i bytte for soja og kyllinger.

\section{Ingen fælles kurs}

Der er med andre ord ikke tale om en fælles, klart fastlagt strategi i Latinamerika. Den venstredrejning der har fundet sted de senere år, er udtryk for en fælles tendens i de fleste latinamerikanske landes befolkninger, som afspejler sig i støtten til bestemte partier og politikere. Der er ikke nødvendigvis tale om en støtte til bestemte ideologier, men snarere til partier og ledere, hvis holdninger afspejler de ønsker, krav og forventninger store dele af befolkningerne har til fremtiden.

Der er ikke tale om støtte til bestemte samfundsmodeller, snarere støtte til modstand mod nyliberalismen og strukturtilpasningspolitikken, støtte til sociale, økonomiske og politiske reformer som kan mindske ulighederne, forbedre levevilkårene for de mange $\mathrm{og}$ skabe $\mathrm{et}$ større demokratisk rum.

Ganske vist viste en undersøgelse i 18 latinamerikanske lande foretaget af FN's udviklingsprogram UNDP i 2004, at $55 \%$ af latinamerikanerne 
er villige til at støtte et autoritært regime frem for en demokratisk regering, hvis det autoritære styre kunne "løse" deres økonomiske problemer. $43 \%$ gik klart ind for en demokratisk styreform, mens resten udtrykte tvivl. Adspurgt om deres holdning til konkrete sider af demokratiet så som ytringsfrihed, svarede et stort flertal dog klart ja.

Det peger på at et flertal i mange lande i de senere år har set venstreorienterede partier og ledere som de bedste til at løse de alvorlige sociale problemer - eller som de mindst kompromitterede og som repræsentanter for de mange nye græsrodsbevægelser, der mere end nogen andre har en tæt og organisk kontakt med alle mulige befolkningsgrupper fra middelklassen og nedefter.

Mere end en fjerdedel af Latinamerikas 560 millioner lever under fattigdomsgrænsen, i nogle lande er det over halvdelen som lever for under det, der svarer til en dollar om dagen. Desuden er de sociale og $\varnothing$ konomiske forskelle enorme. Nogle af verdens 100 rigeste mennesker er latinamerikanere og nogle af verdens allerfattigste lever i Latinamerika.

Tolerancetærsklen over for politiske fejltrin er lav. De nye politiske ledere må foretage en meget vanskelig balancegang mellem de befolkningsgrupper der forventer reformer og forbedringer, og den økonomiske og politiske elite, som er i stand til at undergrave ethvert re- formforsøg. Under deres respektive valgkampe afgav venstrefløjen mange løfter om forbedring af levevilkårene, ophævelse af privilegier, stop for IMF-diktater og ingen eftergivenhed over for USA. Men som en noget frustreret sort regionalpolitiker fra Lulas Arbejderparti PT (Partido dos Trabalhadores) sagde til mig i storbyen Salvador i Nordøstbrasilien i 2004:

"Før vi vandt og kom i regering, så det hele meget enkelt ud. Vi regnede med at der bare var penge nok til det hele på budgettet. Vi skulle bare komme og omprioritere, så pengene i stedet for at gå i korrupte politikeres og embedsmænds lommer kunne gå til forbedringer og reformer. Vi var jo vant til at se politikerne strø om sig med penge. Men da vi så kom ind i regeringskontorerne, opdagede vi at der faktisk var begrænsede midler - og at der ikke var mange muligheder for at rejse flere midler til at opfylde vore valgløfter".

For Brasiliens Lula har der været tale om en særdeles vanskelig balancegang siden 2002. Ikke kun skulle han forsøge at opfylde sine løfter til landets millioner af fattige. Han skulle også sørge for ikke at skræmme den udenlandske og lokale kapital ud af landet, og han skulle tage hensyn til de politiske partier og kræfter han havde været nødt til at alliere sig med for at få flertal i Kongressen. Der blev tale om alliancer med det socialdemokratiske PSDB og det højreorienterede Liberale 
Parti samt en række smågrupper på venstrefløjen.

Til alles overraskelse valgte Lula at overholde Brasiliens forpligtelser over for IMF. Ideen med at betale gælden til IMF ned er tydeligvis at slippe for Fondens stramme krav til og kontrol af landets økonomi. Brasilien er nemlig i lighed med IMF's øvrige debitorer forpligtet til at følge en række anvisninger fra IMF vedrørende landets økonomiske politik, anvisninger der traditionelt har været baseret på en monetaristisk linje, som har indskrænket mulighederne for sociale reformer.

Argentinas Néstor Kirchner har også været ude efter IMF. Da han i december 2005 besluttede at betale Argentinas milliardgæld til IMF, var begrundelsen den samme. I en tale sagde han, at "IMF har handlet mod vort land som ophavsmand til og redskab for en politik, der har skabt fattigdom og lidelse i det argentinske folk". Det var en klar henvisning landets økonomiske sammenbrud i december 2001 og IMF's afvisning af at genforhandle Argentinas gæld en afvisning der kostede landet 4 mia. dollar i 2002.

Lulas overraskende kurs er pragmatisk. Han ønsker at sikre en økonomisk stabilitet for at have et sikrere grundlag at gennemføre de lovede sociale og økonomiske reformer på. Det betyder at kun en mindre del af flere af de lovede reformer er blevet gennemført, og at det har været meget småt med at skaffe jord til de mange millioner af jordløse bønder og landarbejdere, der for manges vedkommende er organiseret $\mathrm{i}$ den slagkraftige MST (Movimento dos Sem Terra, De Jordløses Bevægelse), en af de stærkeste bevægelser i Brasilien - der støttede Lulas valgkamp. Hans løfte er at løfterne vil blive opfyldt.

Han befinder sig imidlertid i et kapløb med tiden, hvor han næppe kan nå at formilde de stadig mere utilfredse jordløse og andre utilfredse inden valget til oktober, hvor han ventes at søge genvalg.

\section{Læren fra Allende}

Andre af de venstreorienterede regeringer på kontinentet må foretage en tilsvarende balancegang, blandt andet for at sikre en tilstrækkelig god økonomi for at kunne gennemføre lovede reformer. Det er således ikke overraskende at Bolivias Evo Morales trods sin radikale diskurs og sit nære venskab med Fidel Castro og Hugo Chávez (som han besøgte straks efter sin valgsejr i december, før han blev indsat i embedet) har taget kontakt med USA for blandt andet forhandle en aftale om narkobekæmpelse.

Han har også taget kontakt med ærkefjenden og naboen Chile for at få sat gang i en løsning på det gamle stridsspørgsmål om Bolivias adgang til havet - og derved også skabe bedre muligheder for landets skrantende økonomi gennem en tættere 
samhandel med den økonomisk stærke nabo.

Chiles Michelle Bachelet lægger næppe den hidtidige økonomiske kurs om. Den har - trods forgængerens socialistiske partitilhørsforhold - ikke været præget af socialistiske tiltag. Chile har under Ricardo Lagos og hans to kristelig demokratiske forgængere fulgt en moderat nyliberalistisk økonomisk kurs for at sikre $\varnothing$ konomisk stabilitet og vækst.

Det er også lykkedes. Landet betragtes i dag som et økonomisk vidunder med vækstrater i asiatisk størrelse. Men det har sin pris. For selv om antallet af chilenere under fattigdomsgrænsen er blevet reduceret, lever $17 \%$ stadig under fattigdomsgrænsen - de fleste af dem blandt landets knap én million indfødte, først og fremmest mapucherne i den sydlige del af landet. Et træk Chile i øvrigt deler med resten af Latinamerika: de fattigste blandt de fattige er de indfødte folk, der i lande som Bolivia og Guatemala udgør over halvdelen af befolkningen.

Valget af Michelle Bachelet har givet de dårligst stillede chilenere håb om at deres forhold vil blive forbedret. Spørgsmålet er imidlertid hvor meget hun kan og vil. I lighed med kolleger som Lula og Tabaré Vázquez kender hun sin samtidshistorie og ved, hvad en mere radikal venstrefløjskurs kan medføre fra modstanderne.

Den skæbne Salvador Allendes forsøg 1970-73 på at gennemføre so- ciale, økonomiske og politiske reformer led som følge af højrefløjens og USA's undergravning af økonomien med efterfølgende økonomisk, socialt og politisk kaos til følge, står mejslet i hendes og chilenernes og mange andre latinamerikaneres erindring. Ingen ønsker det kaos eller det efterfølgende militærdiktatur tilbage. Men samtidig er der er udbredt $\varnothing$ nske om sociale og økonomiske reformer uden indblanding udefra.

\section{Måske, måske...}

Det er det ønske som måske vil bringe den moderat venstreorienterede tidligere oliearbejderleder og overborgmester i Mexico By, Andrés Manuel López Obrador, til magten i Mexico den 1. december. Og måske den sandinistiske dissident og tidligere borgmester i Nicaraguas hovedstad Managua, Herty Lewites, til sejr ved det nicaraguanske valg den 5 . november. Og måske, måske den venstrepopulistiske, nationalistiske, marxistisk inspirerede tidligere artillerioberst Ollanta Humala, til sejr ved præsidentvalget i Peru den 9. april. Men det kan lige så vel blive højrefløjen der vinder.

López Obrador skal i givet fald ikke regne med flertal i Kongressen. Han skal indgå alliancer med de to andre store partier for at få sin politik igennem. Og han skal forsøge at få kontrol med et land, hvor regeringen under den nuværende præsi- 
dent, den konservative Vicente Fox, gradvist har mistet grebet og reelt ingen kontrol har over enklaver, som kontrolleres af narkobaroner i ledtog med etablerede politikere. Ro og orden bliver en af hans højeste prioriteter. Økonomisk genopretning bliver den asketiske politikers anden hovedopgave. Og endelig sociale reformer og styrkelse af demokratiet. Han vil satse på et tættere samarbejde med resten af Latinamerika.

Det er dog usikkert hvor tæt samarbejdet kan blive - dels på grund af Mexicos tætte tilknytning til USA, dels fordi meget afhænger af hvor stærkt de øvrige regeringer vil ønske et tæt formaliseret samarbejde uden at have USA med. Hvilken kurs den kommende leder for Latinamerikas næststørste økonomi vælger, kan blive afgørende for kontinentets fremtidige kurs. Skal man tro på hvad han siger, bliver kursen lagt flere streger til venstre. Men realiteterne i regeringskontorerne kan dæmpe kursændringen.

Venstreorienteringen af Latinamerika er med andre ord ikke så entydig og konsekvent som Bush, Salinas de Gortari og andre kritikere frygter. Selv om Hugo Chávez markerer sig tydeligt som en hovedmodstander til USA, tegner han langtfra hele kontinentet, hvis ledere - trods manges sympati for ham - foretrækker en mere diskret og moderat kurs, der zigzagger mellem hensynet til økonomisk stabilitet, social ret- færdighed og demokrati.

Men måske zigzagger Latinamerika langsomt til venstre.

\section{Efterskrift}

Valget i Peru blev som forventet afgjort i to runder. Ved første valgrunde den 9. april blev den konservative kandidat Lourdes Flores overraskende elimineret. Det betød at Ollanta Humala ved anden valgrunde den 4. juni skulle kappes med tidligere præsident Alan García (198590). García vandt overraskende med $55 \%$ af stemmerne trods sit synderegister som præsident (han efterlod økonomien i en ynkelig forfatning med galoperende inflation og en stor gæld til udlandet, og landet i socialt og politisk kaos). Mange vælgere syntes imidlertid at foretrække den karismatiske populist - der er erklæret socialdemokrat - som det mindste onde frem for Humala, der blandt andet var handicappet af at Venezuelas præsident Hugo Chávez havde erklæret ham sin støtte. Det forstod García at udnytte til fulde. Med García ved roret kommer Peru formentlig til at føre en slingrekurs, hvor han vil forsøge at vise sig som en progressiv og socialt orienteret præsident i stil med Brasiliens Lula og Argentinas Kirchner, og en økonomisk moderat leder, der ikke vil gentage fortidens fejl og derfor vil føre en "ansvarlig" økonomisk politik.

Valget i Mexico den 2. juli gav en 
snæver sejr til den konservative kandidat Felipe Calderon over venstreorienterede modkandidat Andres Manuel Lopez Obrador (36.38 pct. mod Obradors 35.34 pct.). Obrador har krævet en omtælling, og ved redaktionens slutning har Mexicos valgkontor endnu ikke erklæret resultatet officielt, men har opfordret mexicanerne til at afvente resultatet med tålmodighed.
Jens Lohmann er journalist og forfatter specialiseret i latinamerikanske forhold. Hans seneste bog er "Noget for noget. En håndbog om korruption" (Mellemfolkeligt Samvirke). 